\title{
PENGARUH INTELLECTUAL CAPITAL TERHADAP RETURN SAHAM PERUSAHAAN MANUFAKTUR DI INDONESIA
}

\author{
Erlinda Pudji Setyawati ${ }^{\mathrm{a}}$ \\ Andry Irwanto ${ }^{b}$ \\ ${ }^{a}$ Sekolah Pascasarjana Universitas Airlangga ${ }^{b}$ Fakultas Ekonomi dan Bisnis Universitas Airlangga \\ Email: erlindapudjisetyawati@inbox.lv ${ }^{\mathrm{a}}$; andryirwanto149@gmail.com $^{\mathrm{b}}$
}

\section{ARTICLE HISTORY}

Received:

5 July 2020

Revised

11 September 2020

Accepted:

17 Oktober 2020

Online available:

24 November 2020

Keywords:

Capital Employed

Efficiency,

Human Capital

Efficiency,

Structural Capital

Efficiency

\begin{abstract}
Introduction: Peningkatan pengenalan dan pemanfaatan intellectual capital akan membantu meningkatkan kinerja keuangan perusahaan sehingga kepercayaan stakeholder terhadap going concern turut meningkat yang dapat mempengaruhi return saham perusahaan.

Methods: Populasi yang digunakan dalam penelitian ini adalah perusahaan manufaktur yang terdaftar di Bursa Efek Indonesia tahun 2011-2013 sebanyak 131 perusahaan. Teknik pengambilan sampel pada penelitian ini menggunakan random sampling/probability sampling yaitu cara pengambilan sampel yang memberikan kesempatan yang sama kepada setiap elemen populasi untuk dijadikan sampel, dengan cara mencari ringkasan laporan keuangan setiap perusahaan manufaktur dan harga saham aktif di perdagangkan di Bursa Efek Indonesia mulai tahun 2010 hingga 2013, sehingga jumlah sampel yang diambil berdasarkan teknik sampling tersebut sebanyak 50 perusahaan manufaktur yang terdaftar di Bursa Efek Indonesia.

Results: . Dari hasil pengujian menunjukkan bahwa Capital Employed Efficiency (CEE) berpengaruh positif signifikan terhadap return saham perusahaan manufaktur di Bursa Efek Indonesia. Human Capital Efficiency (HCE) berpengaruh positif signifikan terhadap return saham perusahaan manufaktur di Bursa Efek Indonesia. Structural Capital Efficiency (SCE) berpengaruh positif tidak signifikan terhadap return saham perusahaan manufaktur di Bursa Efek Indonesia.

Conclusion and suggestion: Bagi pihak perusahaan, hasil penelitian ini diharapkan dapat digunakan sebagai informasi tambahan dalam pengelolaan modal intelektual perusahaan khususnya Structural Capital Efficiency (SCE) karena variabel ini tidak terbukti dapat meningkatkan return saham.
\end{abstract}




\section{INTRODUCTION}

Penerapan sistem manajemen berdasarkan ilmu pengetahuan di dalam knowledge based business berdampak pada pelaporan keuangan perusahaan. Pelaporan keuangan perusahaan yang biasanya terfokuskan pada kinerja keuangan, dirasa kurang memenuhi di dalam melaporkan kinerja perusahaan. Pengguna laporan keuangan juga memerlukan informasi-informasi lain diluar laporan keuangan, yaitu nilai lebih yang dimiliki oleh perusahaan. Nilai lebih yang dimaksudkan adalah inovasi, penemuan, pengetahuan para karyawan, relasi yang baik dengan pelanggan, teknologi yang dikembangkan, yang sering disebut dengan modal intelektual (Intellectual Capital). Adanya pengungkapan Intellectual Capital, secara tidak langsung berkontribusi secara signifikan dalam mendorong nilai, kompetensi dan keunggulan bersaing perusahaan yang sangat berpengaruh terhadap keputusan para investor. Komponen dari Intellectual Capital terdiri dari human capital, structure capital dan customer (relational) capital (Maditinos et al, 2011). Ketiga komponen tersebut merupakan bagian dari intangible asset, dimana tidak diungkapkan dalam laporan keuangan.

Di Indonesia, fenomena intellectual capital mulai berkembang terutama setelah munculnya PSAK No. 19 (revisi 2009) tentang aktiva tidak berwujud (intangble assest). Meskipun tidak dinyatakan secara eksplisit sebagai intellectual capital, namun lebih kurang intellectual capital telah mendapat perhatian. Menurut PSAK No. 19, aktiva tidak berwujud adalah aktiva non-moneter yang dapat diidentifikasi tanpa wujud fisik aset. Pada PSAK No. 19 (revisi 2009) tahun 2009 tersebut dijelaskan bahwa aktiva atau sumber daya alam yang tidak terwujud yang dimaksud adalah seperti ilmu pengetahuan dan teknologi, lisensi, hak kekayaan intelektual, desain dan implementasi sistem atau proses baru, serta merk produk atau brandnames. Contoh umum intellectual capital lainnya adalah piranti lunak komputer, hak paten, hak cipta, advertising, daftar pelanggan, hak penguasaan hutan, kuota impor, waralaba, hubungan dengan pemasok dan pelanggan, kesetiaan pelanggan, serta hak pemasaran dan pangsa pasar (IAI, 2009).

Walapun dalam PSAK 19 (revisi 2009) secara implisit menyinggung mengenai intellectual capital, tetapi penelitian mengenai kinerja intellectual capital di Indonesia masih terhitung baru dan dalam dunia bisnis praktik intellectual capital masih belum diperkenalkan secara luas di Indonesia. Sebab sampai dengan saat ini, perusahaanperusahaan di Indonesia cenderung menggunakan conventional based dalam membangun bisnisnya, sehingga produk yang dihasilkannya masih miskin teknologi. Selain itu perusahaan-perusahaan tersebut belum memberikan perhatian lebih terhadap human capital structural capital, dan customer capital. Semestinya hal tersebut harus diperhatikan oleh perusahaan karena semua itu merupakan elemen pembangun intellectual capital bagi perusahaan. 
Konsep intellectual capital telah mendapatkan perhatian besar dari berbagai kalangan terutama para akuntan. Fenomena ini menuntut mereka untuk mencari informasi yang lebih rinci mengenai hal-hal yang berkaitan dengan pengelolaan intellectual capital. Pengelolaan tersebut meliputi cara pengidentifikasian dan pengukurannya di dalam laporan tahunan perusahaan (Kuryanto dan Syafruddin, 2008). Peningkatan pengenalan dan pemanfaatan intellectual capital akan membantu meningkatkan kinerja keuangan perusahaan sehingga kepercayaan stakeholder terhadap going concern turut meningkat yang dapat mempengaruhi return saham perusahaan (Atinah dan Muslih, 2011).

Return merupakan imbalan yang diperoleh dari investasi (Halim, 2005). Return merupakan hasil yang diperoleh dari investasi atau tingkat keuntungan yang dinikmati oleh pemodal atas suatu investasi yang dilakukannya (Hartono, 2000: 107). Tanpa keuntungan yang diperoleh dari suatu investasi yang dilakukannya, tentunya investor tidak mau melakukan investasi yang tidak ada hasilnya. Setiap investasi, baik jangka pendek maupun jangka panjang mempunyai tujuan utama yaitu memperoleh keuntungan yang disebut return, baik secara langsung maupun tidak langsung. Informasi mengenai return saham sangat berkaitan dengan informasi pada laporan keuangan. Return saham realisasian dan ekspektasian dapat dihitung berkaitan dengan harga saham dan deviden yang informasinya diketahui pada laporan keuangan. Jika kinerja keuangan pada laporan keuangan perusahaan baik maka pasar akan memberikan sinyal positif sehingga harga saham pun akan meningkat.

Penelitian Bontis (2000) dan Belkaoui (2003) menyatakan bahwa intellectual capital (VAIC ${ }^{\mathrm{TM}}$ ) berpengaruh positif terhadap kinerja keuangan perusahaan. Ulum (2008) yang berhasil membuktikan bahwa intellectual capital (VAIC ${ }^{\mathrm{TM}}$ ) berpengaruh terhadap kinerja keuangan perusahaan. Appuhami (2007) membuktikan terdapat hubungan yang positif signifikan antara value added intellectual coefficient (VAIC) dengan capital gain on share. Berbeda dengan penelitian Diez et al (2010) yang menyimpulkan bahwa walaupun terdapat hubungan antara IC dan penciptaan nilai, namun tidak ada hubungan yang signifikan antara penggunaan indikator human capital dan structural capital dengan variabel-variabel independen selain pertumbuhan penjualan, seperti ROA atau produktivitas. 


\section{LITERATURE REVIEW}

The traditional society

Intellectual Capital

Menurut Ulum (2008) menyatakan bahwa IC adalah istilah yang diberikan kepada aset tidak berwujud yang merupakan gabungan dari pasar dan kekayaan intelektual, yang berpusat pada manusia dan infrastruktur yang memungkinkan perusahaan untuk berfungsi. Ulum (2008) menyatakan bahwa intellectual capital termasuk semua proses dan aset yang tidak biasanya ditampilkan pada neraca dan seluruh aset tidak berwujud (merek dagang, paten dan brands) yang dianggap sebagai metode akuntansi modern. Tidak mudah untuk menyajikan secara tepat pengertian atau definisi dari Intellectual Capital. Pengertian Intellectual Capital pertama kali diperkenalkan oleh Stewart (1998) mendefinisikan IC sebagai pengetahuan intelektual, informasi, properti intelektual, pengalaman yang dapat digunakan secara bersama-sama untuk menciptakan kesejahteraan perusahaan. Williams (2001) mendefinisikan modal intelektual sebagai informasi dan pengetahuan yang diaplikasikan dalam pekerjaan untuk menciptakan nilai. Pendapat ini serupa dengan pendapat Sawarjuwono (2003) yang menyatakan bahwa intelellectual capital merupkan jumlah dari apa yang dihasilkan oleh tiga elemen utama organisasi (human capital, structural capital, dan customer capital) yang berkaitan dengan pengetahuan dan teknologi yang dapat memberikan nilai lebih bagi perusahaan berupa keunggulan bersaing organisasi.

Sebagian besar definisi menunjukkan bahwa Intellectual Capital merupakan aset non fisik yang memiliki tiga karakteristik utama yang meliputi aset tersebut dipandang sebagai sumber profit ekonomi masa depan, tidak memiliki substansi secara fisik, dan aset tersebut dapat dipelihara dan diperdagangkan oleh perusahaan (Eliza, 2011). Dengan demikian, intellectual capital merupakan sumber daya perusahaan yang berbasis pengetahuan dan berupa asset tidak berwujud yang dapat dijadikan nilai tambah bagi perusahaan dengan memperhatikan human capital, structural capital, dan customer capital yang dimiliki perusahaan. Selain itu, Intellectual capital mampu digunakan perusahaan untuk menciptakan inovasi dan persaingan bisnis yang kompetitif Intellectual capital mampu digunakan perusahaan untuk menciptakan inovasi dan persaingan bisnis yang kompetitif.

Edvinson dan Malone (1997) mengelompokkan IC menjadi dua kelompok, yaitu human capital dan structural capital. Ross, et. al (1997) mengelompokkan IC ke dalam tiga aspek yang meliputi human capital, organization capital, dan relational capital. Sveiby (1998) mengelompokkan IC ke dalam tiga kelompok yang terdiri dari employee competence, internal structure, dan external structure. Sveiby mengklasifikasikan intangible ke dalam tiga kategori, yaitu internal structure, external structure, dan employee competence. Internal structure meliputi struktur-struktur organisasi, legal 
parameters, sistem-sistem manual, penelitian dan pengambangan, dan perangkat lunak. External structure mencakup merk dagang dan hubungan antar pelanggan dan pemasok. Employee competence meliputi pendidikan dan pelatihan bagi staf profesional yang merupakan penghasil utama pendapatan.

Menurut Tan, et al (2007), metode pengukuran IC dapat dikelompokkan ke dalam dua kategori, yaitu kategori non moneter dan kategori moneter. Salah satu metode yang termasuk di dalam kategori moneter adalah metode yang diajukan oleh Pulic (2000). Pulic (2000) mengajukan suatu metode untuk mengukur Intellectual Capital, yaitu dengan menggunakan ukuran untuk menilai efisiensi dari nilai tambah (Value Added Intellectual Coefficient - VAIC ${ }^{T M}$ ). VAIC ${ }^{T M}$ menggunakan laporan keuangan perusahaan untuk menghitung efisiensi koefisien tiga jenis modal, yaitu human capital, structural capital, dan capital employed.

1. Capital Employed Efficiency.

Capital Employed Efficiency (CEE) adalah indikator efisiensi nilai tambah modal yang digunakan. CEE menggambarkan berapa banyak nilai tambah perusahaan yang dihasilkan dari modal yang digunakan. CEE yaitu kalkulasi dari kemampuan mengelola modal perusahaan (Imaningati, 2007).

2. Human Capital Efficiency

Human Capital Efficiency (HCE) didefinisikan sebagai pengetahuan, skill, dan pengalaman yang pegawai bawa ketika pegawai meninggalkan perusahaan (Starovic \& Marr, dalam Rifqi 2009). Beberapa dari pengetahuan tersebut bersifat unik untuk setiap individu dan beberapa lainnya bersifat umum, misalnya kapasitas inovasi, kreativitas, know-how dan pengalaman, kapasitas pembelajaran, loyalty, pendidikan formal, dan pendidikan informal (Rifqi 2009). Human capital meliputi pengetahuan individu dari suatu organisasi yang terdapat pada pegawainya dihasilkan melalui kompetensi, sikap, dan kecerdasan intelektual (Rifqi 2009). Kompetensi tersebut dapat meliputi pendidikan dan keterampilan. Sikap dapat meliputi komponen perilaku dari pegawai. Kecerdasan intelektual dapat menjadi pegawai lebih sistematis dalam menyelesaikan masalah dan menciptakan solusi-solusi untuk kemajuan perusahaan. Meskipun pegawai dianggap sebagai aset oleh perusahaan, tetapi mereka bukanlah barang yang biasa dimiliki perusahaan. Human capital merupakan kombinasi warisan genetik, pendidikan, pengalaman, dan sikap tentang hidup dan bisnis (Rifqi 2009). Esensi dari human capital adalah kecerdasan suatu organisasi yang dapat dari kemampuan yang dimiliki oleh orang-orang yang ada di dalam organisasi tersebut. Suatu organisasi akan meningkatkan kinerjanya jika organisasi tersebut dapat memanfaatkan human capital yang dimilikinya.

3. Structural capital efficiency

Published by University of Airlangga.

This is an open access article under the CC BY license (https://creativecommons.org/licenses/by-sa/4.0/) 
Structural capital merupakan pengetahuan dalam organisasi yang independent dari orang-orang atau dengan kata lain dapat diartikan sebagai pengetahuan yang tetap tinggal dalam organisasi meskipun pekerjanya meninggalkan organisasi tersebut (Saleh et al, 2008). Structural capital terdiri atas perjanjian, data base, informasi, sistem, budaya, prosedur, system administrative, kebiasaan, best practice (Saleh et al., 2008). Selain itu, termasuk dalam structural capital adalah semua hal selain manusia yang berasal dari pengetahuan yang berada dalam suatu organisasi termasuk struktur organisasi, strategi, rutinitas, software dan hardware dan semua hal yang nilainya terhadap perusahaan lebih tinggi daripada nilai materinya (Novitasari, 2009).

\section{Return Saham}

Saham adalah surat berharga yang menunjukkan kepemilikan perusahaan sehingga pemegang saham memiliki hak klaim atas dividen atau distribusi lain yang dilakukan perusahaan kepada pemegang sahamnya, termasuk hak klaim atas aset perusahaan, dengan prioritas setelah hak klaim pemegang surat berharga lain dipenuhi jika terjadi likuiditas. Menurut Husnan (2002:303) sekuritas (saham) merupakan secarik kertas yang menunjukkan hak pemodal (yaitu pihak yang memiliki kertas tersebut) untuk memperoleh bagian dari prospek atau kekayaan organisasi yang menerbitkan sekuritas tersebut dan berbagai kondisi yang memungkinkan pemodal tersebut menjalankan haknya, sedangkan menurut Tandelilin (2001:18), saham merupakan surat bukti bahwa kepemilikan atas aset-aset perusahaan yang menerbitkan saham. Jadi, saham adalah surat berharga yang diperdagangkan di pasar modal yang dikeluarkan oleh sebuah perusahaan yang berbentuk Perseroan Terbatas (PT), dimana saham tersebut menyatakan bahwa pemilik saham tersebut adalah juga pemilik sebagian dari perusahaan tersebut.

Para investor termotivasi untuk melakukan investasi salah satunya adalah dengan membeli saham perusahaan dengan harapan untuk mendapatkan kembalian investasi yang sesuai dengan apa yang telah diinvestasikannya. Return merupakan hasil yang diperoleh dari investasi atau tingkat keuntungan yang dinikmati oleh pemodal atas suatu investasi yang dilakukannya (Hartono, 2000: 107). Tanpa keuntungan yang diperoleh dari suatu investasi yang dilakukannya, tentunya investor tidak mau melakukan investasi yang tidak ada hasilnya. Setiap investasi, baik jangka pendek maupun jangka panjang mempunyai tujuan utama yaitu memperoleh keuntungan yang disebut return, baik secara langsung maupun tidak langsung.

Konsep return atau kembalian (Ang 1997:97) adalah tingkat keuntungan yang dinikmati oleh pemodal atas suatu investasi yang dilakukannya. Return saham merupakan income yang diperoleh oleh pemegang saham sebagai hasil dari investasinya di perusahaan tertentu. Return saham dapat dibedakan menjadi dua jenis (Jogiyanto, 
2000), yaitu return realisasi (realized return) dan return ekspektasi (expected return). Return realisasi merupakan return yang sudah terjadi dan dihitung berdasarkan data historis. Return realisasi dapat digunakan sebagai salah satu pengukuran kinerja perusahaan dan dapat digunakan sebagai dasar penentu return ekspektasi dan risiko di masa yang akan datang, sedangkan return ekspektasi merupakan return yang diharapkan terjadi di masa mendatang dan masih bersifat tidak pasti. Return (kembalian) adalah tingkat keuntungan yang dinikmati oleh pemodal atas suatu investasi yang dilakukannya. Tanpa adanya tingkat keuntungan yang dinikmati dari suatu investasi, tentunya investor (pemodal) tidak akan melakukan investasi. Return dapat dibedakan menjadi dua, (Jogiyanto, 2000: 107), yaitu:

Return Harapan (Expected Return), return yang diharapkan akan diperoleh para investor di masa yang akan datang.

a. Return Aktual, (Realized Return), return yang telah terjadi dan dihitung berdasarkan data histories. Return jenis ini dapat digunakan untuk menentukan return harapan dan resiko masa datang.

Menurut Jogiyanto (2000: 107), terdapat dua jenis pengukuran return realisasi, yaitu:

a. Capital gain (loss), merupakan selisih harga investasi sekarang relative dengan harga periode yang lalu. Jika harga investasi sekarang lebih tinggi dari harga investasi periode lalu maka terjadi keuntungan modal (capital gain), dan sebaliknya.

b. Yield, persentase penerimaan kas periodik terhadap harga investasi periode tertentu dari suatu investasi.

Guinan (2009) menjelaskan capital gain sebagai kenaikan nilai aset atau aktiva modal (investasi) di atas harga pembelian. Keuntungan tidak diperoleh hingga aset terjual. Keuntungan modal mungkin terjadi dalam waktu pendek (kurang dari setahun) atau waktu panjang (lebih dari setahun). Selain itu, Guinan (2009) juga menjelaskan bahwa keuntungan modal (capital gain) dapat berupa hasil dari kenaikan harga surat berharga dalam reksadana di atas harga pembelian awal ketika surat berharga tersebut dijual (terealisasi). Pernyataan ini didukung oleh Greer dan Kolbe (2003) yang mengelompokkan capital gain atau losses menjadi dua, yaitu capital gain atau losses jangka pendek (short term) atau jangka panjang (long term). Namun sebelum dikelompokkan berdasarkan periode, Greer dan Kolbe (2003) membagi transaksi yang melibatkan capital assets berdasarkan apakah transaksi tersebut laba (gain) atau rugi (losses). Baru kemudian transaksi tersebut dibagi kembali berdasarkan apakah terjadi pada jangka pendek atau jangka panjang. 
Pendapatan yang akan diperoleh investor tidak bisa diketahui dengan pasti karena laba perusahaan serta kondisi permintaan dan penawaran yang selalu berubah. Pendapatan suatu saham bisa ditentukan dengan rumus sebagai berikut:

Stock Return $=\frac{\left(P_{t}-P_{t-1}\right)}{P_{t-1}} \times 100 \%$

\section{Previous Study and Hypothesis}

Modal relasional mencakup semua hubungan antara perusahaan dengan pelanggan, pemasok, perantara, perwakilan, mitra, pemilik dan pemberi pinjaman Roos, Pike \& Fernstrom (2005). Membangun modal relasional melalui program loyalitas bagi pelanggan, penghargaan penjualan untuk perantara dan pembayaran cepat kepada pemasok akan memberikan kontribusi banyak untuk nilai perusahaan karena meningkatkan loyalitas pihak ketiga bagi perusahaan. Loyalitas yang berubah menjadi promosi tambahan atau brand image yang melekat pada perusahaan. Capital employed merupakan salah satu modal intelektual yang menggambarkan berapa banyak nilai tambah perusahaan yang dihasilkan dari modal yang digunakan. Pengelolaan modal secara maksimal akan meningkatkan value added yang akan meningkatkan kinerja perusahaan pula. Peningkatan kinerja tersebut akan berdampak terhadap return saham yang akan diperoleh investor. Semakin tinggi CEE akan semakin tinggi pula return saham yang diperoleh investor. Oleh karena itu, Capital Employed Efficiency (CEE) berpengaruh positif terhadap return saham. Berdasarkan uraian tersebut, maka diajukan hipotesis penelitian sebagai berikut:

\section{H1 : Terdapat Pengaruh Positif Antara Capital Employed Efficiency Terhadap Return Saham Perusahaan Manufaktur Di Bursa Efek Indonesia.}

Modal manusia mengacu pada sumber daya manusia pada perusahaan yang memiliki pengetahuan yang berguna untuk proses produksi suatu perusahaan dalam mengubah informasi yang diterima dari lingkungan menjadi output yang berguna bagi perusahaan. Menurut Liu (2009), modal manusia tertanam dalam sumber daya manusia perusahaan dan dapat dikembangkan melalui pelatihan dan pendidikan. Pengetahuan ini tidak dapat dipisahkan dari individu sehingga modal ini tidak dimiliki oleh perusahaan. Human capital merupakan salah satu komponen modal intelektual yang berupa pengetahuan, ketrampilan dan kemampuan seseorang yang dapat digunakan untuk menghasilkan layanan profesional. Dengan memiliki sumber daya yang berkualitas, perusahaan dapat mengeksploitasi secara maksimal kemampuan karyawannya dengan baik. Hal tersebut akan meningkatkan value added, sehingga meningkatkan kinerja perusahaan. Dengan meningkatnya kinerja perusahaan diharapkan mampu meningkatkan kepercayaan stakeholder terhadap going concern perusahaan sehingga return saham turut meningkat. Pengelolaan Sumber Daya Manusia (SDM) yang baik dalam perusahaan dapat meningkatkan produktivitas karyawan yang akan meningkatkan 
pendapatan dan profit perusahaan (Imaningati, 2007). Produktivitas karyawan dan profit perusahaan yang semakin meningkat menunjukkan bahwa karyawan semakin baik dalam mengelola aset perusahaan. Hal ini dapat menciptakan kepercayaan stakeholder pada perusahaan tersebut, dengan terciptanya kepercayaan stakeholder maka akan menarik investor untuk menanamkan modal di perusahaan. Semakin tinggi HCE akan semakin tinggi pula return saham yang diperoleh investor. Oleh karena itu, Human Capital Efficiency (HCE) berpengaruh positif terhadap return saham. Berdasarkan uraian tersebut, maka diajukan hipotesis penelitian sebagai berikut:

\section{H2 : Terdapat Pengaruh Positif Antara Human Capital Efficiency Terhadap Return}

\section{Saham Perusahaan Manufaktur Di Bursa Efek Indonesia.}

Modal struktural adalah infrastruktur yang membantu untuk mengubah karyawan perusahaan ide-ide, inovasi dan kreasi dalam bentuk moneter berharga. Modal struktural terdiri sistem perusahaan informasi, struktur organisasi dan kebijakan, strategi serta database. Perkembangan seperti komponen struktural yang mungkin untuk mengurangi biaya dan meningkatkan profitabilitas (Mondal \& Ghosh, 2012). Bernadette (2000) menyatakan bahwa modal struktural mencakup semua aset dan nilainilai yang akan tetap di perusahaan jika semua karyawan meninggalkan perusahaan, sehingga sangat penting sebagai satu-satunya aset yang benar-benar dimiliki oleh perusahaan. Selain itu, Bontis (1998) juga menyatakan bahwa modal struktural mendukung karyawan dalam upaya untuk mencapai kinerja intelektual yang maksimal. Oleh karena itu, baik modal manusia dan modal struktural saling mendukung dalam proses pengembangan nilai perusahaan. Structural Capital merupakan komponen terakhir modal intelektual yang berupa kemampuan organisasi dalam memenuhi proses rutinitas perusahaan untuk mendukung usaha karyawan dalam meningkatkan kinerja perusahaan. Structural Capital mencakup semua pengetahuan dalam perusahaan selain pengetahuan yang ada pada modal manusia, mencakup database, bagan organisasi, proses manual, strategi, rutinitas dan sesuatu yang nilainya lebih tinggi dibandingkan nilai materi (Bontis et al. 2000). Dengan demikian, adanya struktur yang baik, maka perusahaan dapat beroperasi dengan baik pula. Hal ini akan membuat kinerja perusahaan meningkat yang akhirnya akan meningkatkan return saham. Semakin tinggi SCE akan semakin tinggi pula return saham yang diperoleh investor. Oleh karena itu, Structural Capital Efficiency (SCE) berpengaruh positif terhadap return saham. Berdasarkan uraian tersebut, maka diajukan hipotesis penelitian sebagai berikut:

H3 : Terdapat Pengaruh Positif Antara Structural Capital Efficiency Terhadap Return Saham Perusahaan Manufaktur Di Bursa Efek Indonesia.

\section{RESEARCH METHODS}

Published by University of Airlangga.

This is an open access article under the CC BY license (https://creativecommons.org/licenses/by-sa/4.0/) 
Penelitian ini menggunakan alat bantu untuk menjawab hipotesis yaitu berupa regresi linier berganda. Untuk pengukuran intellectual capital digunakan Value Added Intellectual Capital (VAIC ${ }^{\mathrm{TM}}$ ) sebagai proksi. Populasi yang digunakan dalam penelitian ini adalah perusahaan manufaktur yang terdaftar di Bursa Efek Indonesia tahun 2011-2013 sebanyak 131 perusahaan. Teknik pengambilan sampel pada penelitian ini menggunakan random sampling/probability sampling yaitu cara pengambilan sampel yang memberikan kesempatan yang sama kepada setiap elemen populasi untuk dijadikan sampel, dengan cara mencari ringkasan laporan keuangan setiap perusahaan manufaktur dan harga saham aktif di perdagangkan di Bursa Efek Indonesia mulai tahun 2010 hingga 2013, sehingga jumlah sampel yang diambil berdasarkan teknik sampling tersebut sebanyak 50 perusahaan manufaktur yang terdaftar di Bursa Efek Indonesia.

\section{RESULT AND ANALYSIS}

Penelitian ini menggunakan jenis analisis regresi linear sederhana. Data yang telah terkumpul kemudian diolah dengan menggunakan program SPSS 11.1 (Statistical Program For Social). Hasil pengolahan data selengkapnya disajikan pada berikut ini:

Tabel 1.

Hasil Regresi

\begin{tabular}{lccc}
\hline \multicolumn{1}{c}{ Variabel } & Koefisien Regresi & Beta & Probability \\
\hline Konstanta & 7,704 & & 0,236 \\
Capital Employed Efficiency (CEE) & 2,644 & 0,178 & 0,031 \\
Human Capital Efficiency (HCE) & 3,601 & 0,221 & 0,036 \\
Structural Capital Efficiency (SCE) & 0,075 & 0,001 & 0,992 \\
\hline
\end{tabular}

\section{Pengaruh Antara Capital Employed Efficiency (CEE) Terhadap Return Saham}

Capital Employed Efficiency (CEE) memiliki pengaruh signifikan terhadap return saham perusahaan manufaktur yang go public di BEI. Hasil penelitian ini sesuai dengan penelitian Hamidreza dan Masoumeh (2013) yang menyatakan bahwa Capital employed Coefficient memiliki pengaruh terhadap return saham. Capital Employed Efficiency (CEE) menggambarkan seberapa banyak value added yang dihasilkan dari modal fisik yang digunakan. Berpengaruhnya Capital Employed Efficiency (CEE) dengan return saham dikarenakan perusahaan sampel dapat memanfaatkan modal fisik yang ada. Perusahaan manufaktur berani melakukan inovasi-inovasi yang didasarkan dari produk yang dijual di pasar sehingga investor yang membeli saham pada perusahaan manufaktur melihat Capital Employed Efficiency (CEE) yang dimiliki oleh perusahaan, mengingat pada tahun 2015 banyak perusahaan asing atau produk-produk yang dihasilkan oleh negara lain masuk ke Indonesia. Modal relasional mencakup semua hubungan antara perusahaan 
dengan pelanggan, pemasok, perantara, perwakilan, mitra, pemilik dan pemberi pinjaman Roos, Pike \& Fernstrom (2005). Membangun modal relasional melalui program loyalitas bagi pelanggan, penghargaan penjualan untuk perantara dan pembayaran cepat kepada pemasok akan memberikan kontribusi banyak untuk nilai perusahaan karena meningkatkan loyalitas pihak ketiga bagi perusahaan. Loyalitas yang berubah menjadi promosi tambahan atau brand image yang melekat pada perusahaan.

\section{Pengaruh Antara Human Capital Efficiency (HCE) Terhadap Return Saham}

Human Capital Efficiency (HCE) memiliki pengaruh signifikan terhadap return saham perusahaan manufaktur yang go public di BEI. Hasil penelitian ini sesuai dengan penelitian Djamil et al (2013) yang menyatakan bahwa Human Capital Coefficient memiliki pengaruh terhadap retun saham. Modal manusia mengacu pada sumber daya manusia pada perusahaan yang memiliki pengetahuan yang berguna untuk proses produksi suatu perusahaan dalam mengubah informasi yang diterima dari lingkungan menjadi output yang berguna bagi perusahaan. Menurut Liu (2009), modal manusia tertanam dalam sumber daya manusia perusahaan dan dapat dikembangkan melalui pelatihan dan pendidikan. Pengetahuan ini tidak dapat dipisahkan dari individu sehingga modal ini tidak dimiliki oleh perusahaan. Berpengaruhnya Human Capital Efficiency (HCE) terhadap return saham, disebabkan perusahaan manufaktur mampu mengelola dengan baik karyawan yang dimilikinya. Banyaknya perusahaan manufaktur yang berbasis padat karya membuat perusahaan benar-benar mengelola asset yang dimilikinya dengan baik. Pengelolaan Sumber Daya Manusia (SDM) yang baik dalam perusahaan dapat meningkatkan produktivitas karyawan yang akan meningkatkan pendapatan dan profit perusahaan (Imaningati, 2007).

\section{Pengaruh Antara Structural Capital Efficiency (SCE) Terhadap Return Saham}

Structural Capital Efficiency (SCE) memiliki pengaruh tidak signifikan terhadap return saham perusahaan manufaktur yang go public di BEl. Hasil penelitian ini sesuai dengan penelitian Apuhami (2007) yang menyatakan bahwa structural capital coefficient tidak memiliki pengaruh terhadap capital gain. Tidak berpengaruhnya Structural Capital Efficiency (SCE) terhadap return saham disebabkan oleh kebijakan yang berbeda-beda antar perusahaan manufaktur. Disamping itu, setiap kali terdapat perubahan direksi maka kebijakan yang diterapkan akan berubah sehingga kecil kemungkinan Structural Capital Efficiency memiliki pengaruh terhadap return saham. Structural Capital mencakup semua pengetahuan dalam perusahaan selain pengetahuan yang ada pada modal manusia, mencakup database, bagan organisasi, proses manual, strategi, rutinitas dan sesuatu yang nilainya lebih tinggi dibandingkan nilai materi (Bontis et al. 2000). Bernadette (2000) menyatakan bahwa modal struktural mencakup semua aset dan nilainilai yang akan tetap di perusahaan jika semua karyawan meninggalkan perusahaan, 
sehingga sangat penting sebagai satu-satunya aset yang benar-benar dimiliki oleh perusahaan. Selain itu, Bontis (1998) juga menyatakan bahwa modal struktural mendukung karyawan dalam upaya untuk mencapai kinerja intelektual yang maksimal. Oleh karena itu, baik modal manusia dan modal struktural saling mendukung dalam proses pengembangan nilai perusahaan.

\section{CONCLUSION}

Hasil penelitian dan pembahasan yang digunakan sesuai dengan tujuan hipotesis yang dilakukan maka dapat ditarik kesimpulan bahwa Capital Employed Efficiency (CEE) berpengaruh positif signifikan terhadap return saham perusahaan manufaktur di Bursa Efek Indonesia, dapat diartikan bahwa pergerakan kenaikan atau penurunan Capital Employed Efficiency (CEE) diikuti oleh kenaikan atau penurunan return saham. Human Capital Efficiency (HCE) berpengaruh positif signifikan terhadap return saham perusahaan manufaktur di Bursa Efek Indonesia, dapat diartikan bahwa pergerakan kenaikan atau penurunan Human Capital Efficiency (HCE) diikuti oleh kenaikan atau penurunan return saham. Structural Capital Efficiency (SCE) berpengaruh positif tidak signifikan terhadap return saham perusahaan manufaktur di Bursa Efek Indonesia, dapat diartikan bahwa pergerakan kenaikan atau penurunan Structural Capital Efficiency (SCE) tidak diikuti oleh kenaikan atau penurunan return saham. Sebagai bagian akhir dari penelitian ini, maka saran yang dapat disampaikan adalah bagi pihak perusahaan, hasil penelitian diharapkan dapat digunakan sebagai informasi tambahan dalam pengelolaan modal intelektual perusahaan khususnya Structural Capital Efficiency (SCE) karena variabel ini tidak terbukti dapat meningkatkan return saham.

\section{REFERENCES}

Appuhami, B.A. Ranjith. 2007. The Impact of Intellectual Capital on Investors' Capital Gains on Shares: An Empirical Investigation of Thai Banking, Finance \& Insurance Sector. International Management Review, Vol. 3 No. 2.

Belkaoui, Ahmed Riahi. 2003. Teori Akuntansi. Edisi Pertama. Alih Bahasa Marwata S.E., Akt. Salemba Empat: Jakarta.

Bontis, N., W. C. C. Keow, and S. Richardson. 2000. Intellectual Capital and Business Performance in Malaysian Indstries. Journal of Intellectual Capital, Vol. 1, No. 1, hal. $85-100$.

Boove, Courtland L., Marian Burkwood, John V. Thill, dan George P. Dovel. 1993. Management, $4^{\text {th }}$ ed. Singapore: McGraw Hill.

Diez, Jose Maria, Magda Lizet Ochoa, M. Begona Prieto, dan Alicia Santidrian. 2010. Intellectual Capital and Value Creation in Spanish Firms. Journal of Intellectual Capital. Vol.11, No.3, hlm 348-367. 
Djamil, Ari Barkah., Dominique Razafindrambinina., dan Caroline Tandeans. 2013. The Impact of Intellectual Capital on a Firm's Stock Return: Evidence from Indonesia. Journal of Business Studies Quarterly, vol 5, no 2.

Edvinson, Leif and Michele S. Malone. 2007. Intellectual Capital, Realizing Your Company's True Value by Finding Its Hidden Brainpower. New York: Harper Business.

Eliza, Any. 2011. Efisiensi Intellectual Capital dan Pengaruhnya terhadap Kinerja Keuangan: Studi Empiris pada Bank yang Terdaftar di BEJ Tahun 2004 - 2008. Jurnal Akuntansi dan Keuangan, vol. 16 no. 2, Juli - Desember 2011.

Greer, Gaylon E. dan Philip T. Kolbe. 2003. Investment Analysis for Real Estate Decisions, 5th edition. USA: Dearborn ${ }^{\mathrm{TM}}$ Real Edcation.

Guinan, Jack. 2009. Investopedia: Cara Mudah Memahami Istilah Investasi. Jakarta Selatan: PT. Mizan Publika.

Gujarati, Damodaran. 2000. Ekonometrika Dasar. Alih bahasa, Ak. Sumarno Zain. Erlangga.

Halim, Abdul. 2005. Analisis Investasi. Salemba Empat: Jakarta.

Husnan, Suad. 2002. Dasar-dasar Teori Portofolio dan Analisis Sekuritas. Edisi 3.Yogyakarta:AMP YKPN.

Ikatan Akuntan Indonesia. 2009. Standar Akuntansi Keuangan. Salemba Empat: Jakarta.

Imaningati. 2007. Pengaruh Intellectual Capital terhadap Kinerja Perusaahan Real Estate

\& Properti yang Terdaftar di BEI Tahun 2002-2006. Thesis. Universitas Diponegoro. Semarang.

Jogiyanto, Hartono. 2000. Teori Portfolio dan Analisis Investasi. Edisi Pertama. Yogjakarta: BPFE.

Kuryanto, B dan Syafruddin, M. 2008. Pengaruh Modal Intelektual Terhadap Kinerja Perusahaan. Simposium Nasional Akuntansi 11 (SNA 11), 23-24 Juli 2008.

Liu, J. and J, Thomas. 2009. Stock Return and Accounting Earnings. Working Paper. Columbia Business School. New York.

Maditinos, D., Chatzoudes, D., Tsairidis, C., dan Theriou, G. 2011. The Impact of Intellectual Capital on Firm's Market Value and Financial Performance. Journal of Intellectual Capital 12 (1): 132-151.

Mondal, A. dan Ghosh, S.K. 2012. Intellectual Capital And Financial Performance of Indian Banks. Journal of Intellectual Capital, Vol. 13 No. 4, pp. 515-530.

Novitasari, Tera. 2009. Pengaruh Struktur Kepemilikan Terhadap Kinerja Intellectual Capital.

Pulic, Ante. 2000. VAIC ${ }^{T M}$ - An Accounting Tool for IC Management. www.measuringip.at/papers/ham99txt.htm.

Rifqi, Ahmad. 2009. Pengaruh Efektivitas dan Kebutuhan Modal Kerja TerhadapLaba Bersih Industri Barang Konsumsi di Bursa Efek Indonesia. Skripsi Akuntansi S1. Universitas Mercu Buana. Jakarta.

Roos, G., Pike, S., dan Fernstrom, L. 2005. Managing Intellectual Capital In Practice. Burlington: Butterworth-Heinemann. 
Ross, Johan, Gooran Roos, Leiv Edvinson, dan Nicole C. Dragoneti. 1997. Intellectual Capital: Navigating in The New Business Landscape. Journal of Systemic Knowledge Management. February 1997.

Saleh, et al. 2008. A Comprehensive Analytical Approach For Policy Analysis of System Dynamics Models. European Jurnal of Operation Research 208.

Sawarjuwono, Tjiptohadi dan A. P. Kadir. 2003. Intellectual Capital: Perlakuan, Pengukuran, dan Pelaporan (Sebuah Library Research). Journal Akuntansi dan Keuangan. vol. 5, no. 1, hal $35-57$.

Stewart, Thomas A. 1994. Your Company's Most Valuable Assets Intellectual Capital. Fortune, Oktober 1994, Hal 68-74.

Sveiby. 1998. Measuring Intangibles and Intellectual Capital-An Emerging First Standard. http://www.sveiby.com/articles/Intangiblemethods.htm.

Tan, H. P., D. Plowman, dan P. Hancock. 2007. Intellectual Capital and Financial Returns of Companies. Journal of Intellectual Capital, vol. 8 no. 1, hal $76-95$.

Tandelilin, Eduardus. 2001. Analisis Investasi dan Manajemen Portofolio. Edisi Pertama, Cetakan Pertama. BPFE: Yogyakarta.

Ulum, Ihyaul. 2008. Intellectual Capital Performance Sektor Perbankan di Indonesia. Jurnal Akuntansi dan Keuangan, vol 10, no 2, November, 2008.

William, S. M. 2001. Is Intellectual Capital Performance and Disclosure Practices Related?. Journal of Intellectual Capital, vol. 2 No. 3, hal $192-203$. 